\title{
Effect of Dietary Organic Selenium and Zinc on the Internal Egg Quality of Quail Eggs for Different Periods and under Different Temperatures
}

\section{-Author(s)}

Fernandez IB

Cruz VC2

Polycarpo GV

Student, FAPESP grantee, Animal Science School, Universidade Estadual Paulista (UNESP) - Dracena. E-mail: isa bfernandez@hotmail.com

2 Doctor Assistant Professor, Animal Science School, Universidade Estadual Paulista (UNESP) - Dracena. E-mail: valquíria@ dracena.unesp.br

3 Pos Graduate Student in Animal Science, FAPESP grantee, Veterinary. Medicine and Animal Science School, São Paulo State University (UNESP) - Botucatu. E-mail: gupolycarpo@hotmail.com

\section{-Mail Adress}

Isabelle Bossolani Fernandez UNESP - Faculdade de Zootecnia Campus de Dracena

Rod. Cmte. João Ribeiro de Barros, SP 294, $\mathrm{Km} 651$

17.900-000. Dracena, SP, Brazil

Phone: 55-18-38218200

E-mail: isa_bfernandez@hotmail.com

\section{- Keywords}

Eggs, organic trace minerals, quails, storage, temperature.

\section{-Acknowledgements}

The authors than FAPESP for financing this study and the grant, and the company Alltech for providing the chelated trace minerals Se and $\mathrm{Zn}$

\begin{abstract}
The objective of this study was to evaluate the internal quality of eggs of Japanese quails fed diets supplemented with chelated selenium and zinc. The experiment was carried out for 120 days, and 144 birds were divided in random blocks into four treatments (control; $0.3 \mathrm{ppm}$ Se; 60 ppm Zn and 0.3 ppm Se +60 ppm Zn). Ten, 14, 18, and 22 weeks after the beginning of lay, eggs were collected and stored under two different temperatures (environmental temperature or refrigeration) and for 10, 20, and 30 days. Eggs were analyzed for: Haugh units $(\mathrm{HU})$, albumen height $(\mathrm{AH})$, yolk index $(\mathrm{YI})$, and albumen index $(\mathrm{Al})$. Parameters were only statistically influenced by the interaction between dietary treatment and storage time. It was concluded that the addition of organic Se and Zn influenced internal egg quality when eggs were stored up to 20 days, independently of storage temperature, suggesting that the combined supplementation of organic Se and $\mathrm{Zn}$ improve internal egg quality and extend egg shelf life.
\end{abstract}

\section{INTRODUCTION}

According to Souza et al. (2001) and Turatti (2001), eggs have high nutritional values, and are one of the alternatives to solve malnutrition problems in Latin America. Eggs supply protein, fat, minerals, and vitamins, and have low calorie content and low cost, and are considered as one of the most reliable sources of these compounds (Stadelman, 1999). Due to their high biological value, egg proteins are used as standard when measuring the nutritional quality of food proteins (Sakanaka et al., 2000).

The egg is one of the most frequently consumed food items in the world, and in Western societies, the highest consumption is of chicken eggs (Muller \& Tobin, 1996). However, the market of quail eggs is increasing, being offered mainly as a side dish in restaurants. Quail eggs present, in average, $74.6 \%$ humidity; $13.1 \%$ protein; $1.1 \%$ minerals, and $11.2 \%$ lipids (Panda \& Singh, 1990), and calcium, phosphorus, iron, vitamin A and energy contents per $100 \mathrm{~g}$ are 59mg, 220mg, $3.8 \mathrm{mg}, 300 \mathrm{IU}$ and $158 \mathrm{kcal}$, respectively. The consumption of six quail eggs $(10 \mathrm{~g} / \mathrm{egg})$ per day, which is equivalent to one chicken egg $(60 \mathrm{~g})$, supplies $4.4,16.5$, and $22.8 \%$ of the daily requirements of calcium, phosphorus, and iron, respectively, of children between one and six years of age, considering the daily average consumption of calcium and phosphorus (800mg) and iron (10mg) as recommended by the NRC (1994).

Despite the nutritional value of egg mentioned above, egg quality must be taken into account, and care must be taken to prevent the development of bacteria and fungi of the genera Penicillium, Sporotrichum, Mucor, Cladosporium, and Alternaria, which are the 
main microorganisms responsible for the physical and chemical changes observed in the egg after lay, making egg unfit for consumption (Patrício, 2003). This requires proper storage, that is, egg must be maintained under refrigeration, as from lay to consumption, as extensive storage periods may reduce internal egg quality. Inadequate packages and the exposure of eggs to contaminant agents, when eggs are stored under high temperature and low humidity, lead to faster biochemical changes of the albumen and increase the probability of egg contamination by pathogens, reducing their shelf life.

Egg quality impairment is mainly associated to the loss of water and carbon dioxide during storage, which are proportional to the increase in environmental temperature (Leandro et al., 2005).

As inadequate storage conditions persist, the albumen becomes more liquid. The continuous loss of carbon dioxide increases alkalinity inside the egg, changing the flavor, and consequent palatability of the egg (Moreng \& Avens, 1990).

The results of studies on the effect of organic trace minerals on egg quality are few and controversial, and therefore, the present study aimed at analyzing the internal quality of eggs submitted to different storage periods under environmental temperature or under refrigeration produced by quails (Coturnix coturnix japonica) fed diets containing or not organic selenium and zinc.

\section{MATERIALS AND METHODS}

The experiment was carried out at the Poultry Sector of Universidade Estadual Paulista (UNESP), Dracena campus, Brazil. In the study, 144 female quails were housed at 35 days of age in a conventional house with two batteries of 24 galvanized-iron cages $(0.17 \mathrm{~m}$ high $\times 0.35 \mathrm{~m}$ wide $\times 0.35 \mathrm{~m}$ deep). Feeds were offered $\mathrm{ad}$ libitum in trough feeders in the morning and evening, and water was available also ad libitum in nipple drinkers. The lighting program adopted was $19 \mathrm{~h}$ of light, which is higher than the recommended time, aiming at stimulating feed intake during the cooler periods of the day, as the region of Dracena presents high environmental temperatures, directly interfering in feed intake and egg production. Internal house temperature was daily recorded in the morning using a maximum-minimum thermometer placed in the center of the house. The recorded maximum and minimum temperatures were $42^{\circ}$ to $44^{\circ} \mathrm{C}$ and $20^{\circ}$ to $24^{\circ} \mathrm{C}$, respectively. The experimental diets were based on corn and soybean meal, and formulated according to the recommendations of Murakami and Ariki (1998), and diets were balanced according to the ingredient composition tables of Rostagno et al. (2005) (Table 1).

\begin{tabular}{|c|c|c|c|c|}
\hline \multirow[t]{2}{*}{ Ingredients \% } & \multicolumn{4}{|c|}{ Treatments } \\
\hline & Control & Se & $\mathrm{Zn}$ & $\mathrm{Se}+\mathrm{Zn}$ \\
\hline Corn & 63.507 & 63.507 & 63.501 & 63.501 \\
\hline Soybean meal & 27.622 & 27.622 & 27.622 & 27.622 \\
\hline Salt/ $\mathrm{NaCl}$ & 0.400 & 0.400 & 0.400 & 0.400 \\
\hline $\begin{array}{l}\text { Mineral and vitamin } \\
\text { supplement }{ }^{1}\end{array}$ & 0.500 & 0.500 & 0.500 & 0.500 \\
\hline Calcitic limestone & 4.864 & 4.864 & 4.864 & 4.864 \\
\hline Dicalcium phosphate & 2.602 & 2.602 & 2.602 & 2.602 \\
\hline DL-methionine & 0.169 & 0.169 & 0.169 & 0.169 \\
\hline Lysine & 0.336 & 0.336 & 0.336 & 0.336 \\
\hline Selenium-methionine ${ }^{2}$ & 0 & 0.00003 & 0 & 0.00003 \\
\hline Zinc $^{2}$ & 0 & 0 & 0.006 & 0.006 \\
\hline Total & 100.00 & 100.00 & 100.00 & 100.00 \\
\hline \multicolumn{5}{|l|}{ Calculated composition } \\
\hline Crude protein, (\%) & 18 & 18 & 18 & 18 \\
\hline $\begin{array}{l}\text { Metabolizable energy, } \\
\text { (kcal/kg) }\end{array}$ & 2800 & 2800 & 2800 & 2800 \\
\hline Calcium, (\%) & 2.50 & 2.50 & 2.50 & 2.50 \\
\hline Available phosphorus, (\%) & 0.55 & 0.55 & 0.55 & 0.55 \\
\hline Methionine+Cystine, (\%) & 0.76 & 0.76 & 0.76 & 0.76 \\
\hline Lysine, (\%) & 1.30 & 1.30 & 1.30 & 1.30 \\
\hline
\end{tabular}

1 - Mineral and vitamin supplement - Composition/kg product: Folic acid, 61.75mg; Biotin, 25mg; Choline, 60,000mg; Niacin, 2,475mg; Calcium pantothenate, $712.5 \mathrm{mg}$; Vit. A, 1,562,500 IU; Vit. B1, 370mg; Vit. B12, 5,000mcg; Vit. B2, 850mg; Vit. B6, 247.5mg; Vit. D3, 625,000 UI; Vit. E, 3,125mg; Vit. K, 245mg; Copper, 1,875mg; lodine, 126.5mg; Manganese, 11,437.5mg; Selenium, 57mg; Zinc, 15,057mg; Methionine, 350g; Antioxidant, 100mg. 2 - Se and Zn Alltech do Brasil.

Ten, 14, 18, and 22 after the onset of lay, three eggs, corresponding to different storage periods (10, 20, and 30 days), were collected from each cage and separated per treatment, totaling 18 eggs per treatment, with 72 eggs stored under environmental temperature and 72 under refrigeration. After collection, eggs were washed, placed in duly identified quail-egg packages, with four packages stored under refrigeration (refrigerator at $4^{\circ} \mathrm{C}$ ) and four under environmental temperature, totaling 144 eggs.

At 10, 20, and 30 days of storage, 24 eggs maintained in environmental temperature (six eggs per treatment) and 24 under refrigeration were submitted to internal egg quality assessment. The evaluated 
characteristics were albumen index (Al), yolk index (YI), Haugh units (HU), and albumen height (AH).

The temperature of eggsstored in the refrigeratorwas $4^{\circ} \mathrm{C}$, whereas minimum and maximum temperatures recorded for eggs stored at environmental temperature were 23 and $27^{\circ} \mathrm{C}$, respectively.

Eggs were numbered, weight in $0.01 \mathrm{~g}$ precision scale, broken onto a completely black flat glass surface, and measured as to albumen height and longitudinal and transversal albumen diameter between external albumen edge and the yolk, with the aid of a $0-150 \mathrm{~mm}$ Digimess pachymeter.

The mean of the obtained values was used in the formula presented by Card and Nesheim (1978): $\mathrm{HU}=$ $100 \times \log \left(H+7.57-1.7 W^{0.37}\right)$, where: $H=$ albumen height $(\mathrm{mm})$ and $\mathrm{W}=$ egg weight $(\mathrm{g})$.

Yolk index measures yolk quality and was evaluated as the ratio between yolk height $(\mathrm{YH})$ and yolk diameter $(\mathrm{YD})$ as $(\mathrm{YI})=\mathrm{YH} / \mathrm{YD}$.

Albumen index was calculated using mean longitudinal and transversal albumen diameters. Albumen height was measured at the dense part of the albumen $0.5 \mathrm{~cm}$ from the yolk edge using a $0-150 \mathrm{~mm}$ Digimess pachymeter.

A randomized block experimental design with a $4 \times 2 \times 2$ factorial arrangement (4 diets - control; 0.3 ppm Se; 60 ppm Zn and 0.3 ppm Se +60 ppm Zn; 2 storage periods - 10 and 20 days and 2 temperatures environmental and refrigeration) was applied.

Data were submitted to analysis of variance (ANOVA), using SAEG (2005) software package. Means were compared by the test of Tukey at $5 \%$ probability level.

\section{RESULTS AND DISCUSSION}

The results relative to eggs stored for 30 days under both tested temperatures are not presented as the eggs did not present conditions to be analyzed.

The analysis of internal egg quality parameters did not show any interaction ( $p>0.05)$ between diet and storage temperature during the experimental period (Table 2).

According to Scott and Silversides (2000) and Carvalho et al. (2007), the higher the yolk index, the lower is albumen index and height, and this tends to get worse as storage temperature increases and as birds age.

There was no influence of dietary Se and Zn on egg quality as a function of storage temperature $(p<0.05)$. In addition, internal quality parameters of eggs stored under refrigeration or not were not different. This may be due to deficient supply of $\mathrm{Zn}$ and Se in the experimental because no optimal recommendations of these trace minerals (individually or not) for quails reared under Brazilian climate conditions were found in literature. However, temperature increase intensifies sensorial changes in eggs, reducing their quality, as eggs are susceptible to bacterial proliferation. According to Piccinin et al. (2004), the quality of Japanese quail eggs stored at environmental temperature $\left(25^{\circ} \mathrm{C}\right)$ is reduced faster than that those stored at $4^{\circ} \mathrm{C}$ (refrigerated).

In the present study, albumen height and Haugh units of eggs stored for 10 and 20 days were significantly $(p<0.05)$ affected by the interaction between diet and storage period (Table 3 ).

When treatments were individually analyzed (control; $0.3 \mathrm{ppm} \mathrm{Se} ; 60 \mathrm{ppm} \mathrm{Zn}$ and $0.3 \mathrm{ppm}$ Se + 60 ppm Zn), no differences were observed in $\mathrm{AH}$ and $\mathrm{HU}$ ( $p>0.05$ ) among the storage periods, except for the inclusion of the combination of $\mathrm{Se}+\mathrm{Zn}$ (T4), which resulted in higher $\mathrm{HU}(\mathrm{p}<0.05)$ in eggs stored for 10 days. However, when storage periods were individually analyzed, higher $\mathrm{AH}$ and $\mathrm{HU}$ were observed

Table 2 - Mean albumen height, yolk index, albumen index and Haugh units of quail eggs stored at environmental temperature and under refrigeration during the entire experimental period (10-22 weeks after the onset of lay).

\begin{tabular}{|c|c|c|c|c|c|c|}
\hline \multirow{2}{*}{ Parameters } & \multirow{2}{*}{ Temperature } & \multicolumn{4}{|c|}{ Diets } & \multirow{2}{*}{$C V *(\%)$} \\
\hline & & T1 & T2 & T3 & T4 & \\
\hline \multirow{2}{*}{ Albumen height } & Environmental & 2.71 & 2.33 & 2.96 & 3.02 & 30.96 \\
\hline & Refrigeration & 3.35 & 3.29 & 3.38 & 3.42 & \\
\hline \multirow{2}{*}{ Yolk index } & Environmental & 0.26 & 0.25 & 0.31 & 0.26 & 39.90 \\
\hline & Refrigeration & 0.47 & 0.50 & 0.43 & 0.47 & \\
\hline \multirow{2}{*}{ Albumen index } & Environmental & 0.44 & 0.43 & 0.41 & 0.44 & 17.66 \\
\hline & Refrigeration & 0.37 & 0.37 & 0.37 & 0.37 & \\
\hline \multirow{2}{*}{ Haugh units } & Environmental & 79.57 & 76.79 & 81.72 & 81.43 & 8.21 \\
\hline & Refrigeration & 83.86 & 83.04 & 83.44 & 84.09 & \\
\hline
\end{tabular}

T1: control; T2: 0.3 ppm Se; T3: 60 ppm Zn; T4: 0.3 ppm Se + 60 ppm Zn. *CV: coefficient of variation. 
Table 3 - Mean albumen height, yolk index, albumen index and Haugh units of quail eggs stored for 10 and 20 days during the experimental period (10-22 after the onset of lay).

\begin{tabular}{|c|c|c|c|c|c|c|}
\hline \multirow{2}{*}{ Parameters } & \multirow{2}{*}{ Storage period } & \multicolumn{4}{|c|}{ Diets } & \multirow[t]{2}{*}{$\mathrm{CV}^{*}(\%)$} \\
\hline & & T1 & T2 & T3 & T4 & \\
\hline \multirow[t]{2}{*}{ Albumen height } & 10 days & 3.05Aa & 3.00Aa & 3.32Ab & $3.43 \mathrm{Ab}$ & \multirow{2}{*}{30.96} \\
\hline & 20 days & 3.01Ab & 2.61 Aa & $3.02 \mathrm{Ab}$ & 3.01Ab & \\
\hline \multirow[t]{2}{*}{ Yolk index } & 10 days & 0.38 & 0.43 & 0.42 & 0.40 & \multirow{2}{*}{39.90} \\
\hline & 20 days & 0.34 & 0.33 & 0.32 & 0.33 & \\
\hline \multirow[t]{2}{*}{ Albumen index } & 10 days & 0.43 & 0.41 & 0.41 & 0.41 & \multirow{2}{*}{17.66} \\
\hline & 20 days & 0.38 & 0.39 & 0.38 & 0.40 & \\
\hline \multirow[t]{2}{*}{ Haugh units } & 10 days & 82.14Aa & 81.34Aa & 84.04Ab & $84.44 \mathrm{Bb}$ & \multirow{2}{*}{8.21} \\
\hline & 20 days & $81.30 A b$ & 78.49Aa & $81.12 \mathrm{Ab}$ & $81.08 \mathrm{Ab}$ & \\
\hline
\end{tabular}

T1: control; T2: 0.3 ppm Se; T3: 60 ppm Zn; T4: 0.3 ppm Se + 60 ppm Zn. A, B Means in the same column followed by different capital letters are significantly different $(p<0.05)$ by the test of Tukey. a, b Means in the same row followed by different small letters are significantly different ( $<<0.05)$ by the test of Tukey. ${ }^{*} \mathrm{CV}$ : coefficient of variation.

in the eggs stored for 10 days laid by quails fed diets supplemented only with $\mathrm{Zn}$ (T3) and the combination of Se and Zn (T4), as compared to the diet with individual supplementation of Se (T2) and the control $\operatorname{diet}(\mathrm{T} 1)$, which were statistically similar. At 20 days of storage, the lowest $\mathrm{AH}$ and $\mathrm{HU}$ were obtained with the treatment with individual supplementation of Se $(\mathrm{T} 2)$, relative to the other treatments, which were not different.

Correia et al. (2000), evaluating eggs of chicken layers fed diets supplemented or not with organic selenium, did not find any effect of Se supplementation on the internal quality of eggs stored at environmental temperature for up to 21 days.

In the present study, the significant effect of organic Se and Zn supplementation on egg quality showed that the addition of these trace minerals increase the shelf life of quail eggs stored up to 20 days.

The lack of influence of the dietary treatments on $\mathrm{YI}$ is consistent with the findings of Scatolini (2007), who evaluated the effects of the dietary supplementation of organic or inorganic combinations of $\mathrm{Mn}, \mathrm{Zn}$, $\mathrm{Se}, \mathrm{Fe}$, and $\mathrm{Cu}$, and $\mathrm{Mn}, \mathrm{Zn}$, and Se individually or combined, on chicken eggs stored for 14 days at environmental temperature and did not observed any effect on $\mathrm{Yl}$.

The albumen index results obtained in the present experiment are similar to those of Santos et al. (2009), who did not find any influence of different storage periods (1-30 days) on that parameter.

The results showed that supplemental dietary Se and $\mathrm{Zn}$ helped reducing the damage caused by storage in eggs stored up to 20 days, as demonstrated by the higher albumen height and Haugh unit values, essential egg classification parameters.
There was significant effect of the interaction between storage temperature and period only on $\mathrm{AH}$ in eggs laid 10 weeks after the onset of lay (Table 4). Eggs stored under refrigeration for 10 days presented higher $\mathrm{AH}(\mathrm{p}<0.05)$, whereas there was no influence of storage temperature on $\mathrm{AH}$ of eggs stored for 20 days.

When storage periods were analyzed according to each storage temperature, it was observed that $\mathrm{AH}$ of eggs maintained at environmental temperature for 10 days was not different ( $p>0.05$ ) from that of those stored at the same temperature for 20 days. However, eggs stored for 10 days under refrigeration presented higher $\mathrm{AH}(\mathrm{p}<0.05)$ as compared to those stored for 20 days under refrigeration.

The interaction between storage temperature and period significantly affected the parameters $\mathrm{AH}, \mathrm{Al}$, and $\mathrm{HU}$ (Table 5) of eggs laid by 14 weeks after the onset of lay.

The analysis of storage temperature as a function of storage period did not show any $\mathrm{AH}$ or $\mathrm{HU}$ differences ( $p>0.05)$ between eggs stored for 10 days at environmental temperature or under refrigeration, but eggs stored for 20 days under refrigeration presented higher $\mathrm{AH}$ and $\mathrm{HU}(\mathrm{p}<0.05)$ as compared to those maintained at environmental temperature.

Higher Al $(p<0.05)$ was observed in eggs stored at environmental temperature for 10 and 20 days relative to those stored under refrigeration.

When storage periods were analyzed as a function of storage temperatures, it was verified that the $\mathrm{AH}$ and $\mathrm{HU}$ of eggs maintained at environmental temperature for 10 days were not different ( $p>0.05)$ from those stored at this temperature for 20 days, but refrigerated eggs stored for 20 days presented higher $(p<0.05) \mathrm{AH}$ and $\mathrm{HU}$ than those stored for 10 days under refrigeration. 
Table 4 - Mean albumen height, yolk index, albumen index and Haugh units of eggs laid by 10 weeks after the onset of lay and stored at environmental temperature and under refrigeration for 10 and 20 days.

\begin{tabular}{|c|c|c|c|c|}
\hline \multirow{2}{*}{ Parameters } & \multirow{2}{*}{ Storage temperature } & \multicolumn{2}{|c|}{ Storage period } & \multirow{2}{*}{$\mathrm{CV}^{*}(\%)$} \\
\hline & & 10 & 20 & \\
\hline \multirow[t]{2}{*}{ Albumen height } & Environmental & 3.02Ba & 2.42Aa & \multirow{2}{*}{26.35} \\
\hline & Refrigeration & 4.31Aa & $2.66 \mathrm{Ab}$ & \\
\hline \multirow[t]{2}{*}{ Yolk index } & Environmental & 0.27 & 0.15 & \multirow{2}{*}{16.22} \\
\hline & Refrigeration & 0.51 & 0.45 & \\
\hline \multirow[t]{2}{*}{ Albumen index } & Environmental & 0.43 & 0.40 & \multirow{2}{*}{14.43} \\
\hline & Refrigeration & 0.42 & 0.36 & \\
\hline \multirow[t]{2}{*}{ Haugh units } & Environmental & 80.38 & 77.14 & \multirow{2}{*}{8.30} \\
\hline & Refrigeration & 88.76 & 78.87 & \\
\hline
\end{tabular}

$A, B$ - Means in the same column followed by different capital letters are significantly different $(p<0.05)$ by the test of Tukey. $a$, b Means in the same row followed by different small letters are significantly different $(\mathrm{p}<0.05)$ by the test of Tukey. ${ }^{*} \mathrm{CV}$ : coefficient of variation.

Table 5 - Mean albumen height, yolk index, albumen index and Haugh units of eggs laid by 14 weeks after the onset of lay and stored at environmental temperature and under refrigeration for 10 and 20 days.

\begin{tabular}{|c|c|c|c|c|}
\hline \multirow{2}{*}{ Parameters } & \multirow{2}{*}{ Storage temperature } & \multicolumn{2}{|c|}{ Storage period } & \multirow[t]{2}{*}{$\mathrm{CV}^{*}(\%)$} \\
\hline & & 10 & 20 & \\
\hline \multirow[t]{2}{*}{ Albumen height } & Environmental & 2.96Aa & $2.55 \mathrm{Ba}$ & \multirow{2}{*}{21.78} \\
\hline & Refrigeration & 3.17Ab & 4.24Aa & \\
\hline \multirow[t]{2}{*}{ Yolk index } & Environmental & 0.19 & 0.18 & \multirow{2}{*}{16.81} \\
\hline & Refrigeration & 0.45 & 0.47 & \\
\hline \multirow[t]{2}{*}{ Albumen index } & Environmental & $0.46 \mathrm{Ab}$ & $0.54 \mathrm{Aa}$ & \multirow{2}{*}{14.39} \\
\hline & Refrigeration & $0.37 \mathrm{Ba}$ & $0.38 \mathrm{Ba}$ & \\
\hline \multirow[t]{2}{*}{ Haugh units } & Environmental & 81.64Aa & 78.87Ba & \multirow{2}{*}{7.02} \\
\hline & Refrigeration & $83.88 \mathrm{Ab}$ & 88.95Aa & \\
\hline
\end{tabular}

A, B Means in the same column followed by different capital letters are significantly different $(p<0.05)$ by the test of Tukey. $a$, $b$ Means in the same row followed by different small letters are significantly different $(p<0.05)$ by the test of Tukey. ${ }^{*} \mathrm{CV}$ : coefficient of variation.

In addition, higher $(p<0.05)$ Al was obtained in eggs maintained at environmental temperature for 20 days as compared to those stored for 10 days under this temperature. Under refrigeration, Al was similar ( $p>0.05$ ) in eggs stored for 10 and 20 days.

The effect of the interaction between storage temperature and period was only significant on Al (Table 6) in eggs laid by 18 weeks after the onset of lay.

The analysis of temperature within each storage period showed that Al was higher $(p<0.05)$ in eggs stored for 10 days at environmental temperature. After 20 days of storage, eggs maintained at environmental temperature or under refrigeration presented similar Al.

When storage periods were analyzed with storage temperatures, it was observed that refrigerated eggs stored for 10 days were not different $(p>0.05)$ from those stored under refrigeration for 20 days as to $\mathrm{Al}$; however, those maintained for 10 days at environmental temperature presented higher $\mathrm{Al}(\mathrm{p}<0.05)$ than those stored for 20 days at this temperature.
There was no interaction ( $p>0.05$ ) between storage temperature and period for internal quality parameters evaluated in eggs laid by 22 weeks after the onset of lay (Table 7).

The results presented in the tables showing internal quality results of eggs laid when quails were 10 (Table 4), 14 (Table 5), 18 (Table 6), and 22 (Table 7) after the onset of lay are consistent with the findings of Moura et al. (2008), who observed that refrigeration helped to delay the negative effect of storage time on egg quality, thereby increasing the shelf life of fresh eggs.

The findings of the present study also agree with the results of Brito et al. (2004), who verified a significant reduction in albumen height in eggs laid by Lohmann LSL layers stored at environmental temperature as compared to those stored under refrigeration.

On the other hand, the obtained mean yolk index values are different than those observed by Santos et al. (2009), which were higher in eggs stored for 21 days at environmental temperature relative to those 
Table 6 - Mean albumen height, yolk index, albumen index and Haugh units of eggs laid by 18 weeks after the onset of lay and stored at environmental temperature and under refrigeration for 10 and 20 days.

\begin{tabular}{|c|c|c|c|c|}
\hline \multirow{2}{*}{ Parameters } & \multirow{2}{*}{ Temperature } & \multicolumn{2}{|c|}{ Storage period } & \multirow{2}{*}{$C V *(\%)$} \\
\hline & & 10 & 20 & \\
\hline \multirow[t]{2}{*}{ Albumen height } & Environmental & 2.17 & 2.00 & \multirow{2}{*}{19.96} \\
\hline & Refrigeration & 3.19 & 3.39 & \\
\hline \multirow[t]{2}{*}{ Yolk index } & Environmental & 0.19 & 0.15 & \multirow{2}{*}{52.48} \\
\hline & Refrigeration & 0.49 & 0.59 & \\
\hline \multirow[t]{2}{*}{ Albumen index } & Environmental & $0.47 \mathrm{Aa}$ & $0.40 A b$ & \multirow{2}{*}{14.41} \\
\hline & Refrigeration & $0.37 \mathrm{Ba}$ & $0.35 \mathrm{Aa}$ & \\
\hline \multirow[t]{2}{*}{ Haugh units } & Environmental & 76.10 & 75.69 & \multirow{2}{*}{5.82} \\
\hline & Refrigeration & 81.85 & 84.02 & \\
\hline
\end{tabular}

A, B - Means in the same column followed by different capital letters are significantly different $(p<0.05)$ by the test of Tukey. $a$, b Means in the same row followed by different small letters are significantly different $(p<0.05)$ by the test of Tukey. ${ }^{*} \mathrm{CV}$ : coefficient of variation.

Table 7 - Mean albumen height, yolk index, albumen index and Haugh units of eggs laid by 22 weeks after the onset of lay and stored at environmental temperature and under refrigeration for 10 and 20 days.

\begin{tabular}{|c|c|c|c|c|}
\hline \multirow{2}{*}{ Parameters } & \multirow{2}{*}{ Storage temperature } & \multicolumn{2}{|c|}{ Storage period } & \multirow{2}{*}{$C V *(\%)$} \\
\hline & & 10 & 20 & \\
\hline \multirow[t]{2}{*}{ Albumen height } & Environmental & 2.45 & 3.07 & \multirow{2}{*}{37.70} \\
\hline & Refrigeration & 2.54 & 3.12 & \\
\hline \multirow[t]{2}{*}{ Yolk index } & Environmental & 0.22 & 0.50 & \multirow{2}{*}{19.27} \\
\hline & Refrigeration & 0.24 & 0.59 & \\
\hline \multirow[t]{2}{*}{ Albumen index } & Environmental & 0.40 & 0.31 & \multirow{2}{*}{13.78} \\
\hline & Refrigeration & 0.39 & 0.33 & \\
\hline \multirow[t]{2}{*}{ Haugh units } & Environmental & 78.55 & 81.84 & \multirow{2}{*}{8.84} \\
\hline & Refrigeration & 79.05 & 82.38 & \\
\hline
\end{tabular}

stored at the same temperature for 7 and 14 days.

Independently from storage time, it was observed that the albumen index of eggs maintained at environmental temperature was numerically higher as compared to that of refrigerated eggs. According to Sauveur (1993), the main physical and chemical changes of egg albumen after lay are $\mathrm{CO}_{2}$ and water loss through the evaporation of external albumen fluid, biochemical changes of proteins, and water loss to the yolk through the internal albumen fluid.

No results relative to day 30 of egg storage are presented due to the poor conditions of the eggs, which was also observed by Baptista (2002) when evaluating internal quail egg quality as a function of storage temperature.

The results obtained in the present study evidence the negative effects of storing quail eggs at environmental temperature on internal egg quality, as low AH (albumen height) and HU (Haugh unit) values indicate worse internal egg quality.
Therefore, the use of organic trace mineral sources can be used in diet quails, as the evaluated parameters of internal egg quality were not affected. However, the levels of the studied trace minerals may have been higher than those effectively required by birds to optimize egg quality, as dietary trace mineral inclusion levels used in Brazil are higher than those required by quails.

Considering storage conditions, it was found that the quality of eggs maintained at environmental temperature was impaired, and that refrigeration attenuates the adverse effects of long storage periods, increasing the shelf life of fresh eggs.

\section{REFERENCES}

Baptista RF. Avaliação da qualidade interna de ovos de codorna (Coturnix coturnix japonica) em função da temperatura de armazenagem [dissertação]. Niterói (RJ): Universidade Federal Fluminense; 2002. 
Barbosa NAA. Efeito da temperatura e do tempo de armazenamento na qualidade interna de ovos de poedeiras comerciais. Poultry Science 2004; 6:60-65.

Brito $A B$, Jackson RM, Stringhini JH. Avaliação do período de estocagem dos ovos de poedeiras comerciais de 33 e 87 semanas de idade sobre a qualidade interna. Reunião Anual da Sociedade Brasileira de Zootecnia; 2004; Campo Grande, Mato Grosso do Sul. Brasil. CD-ROM.

Carvalho FB, Stringhini JH, Filho RMJ, Leandro NSM, Café MB, Deus HSB. Qualidade interna e da casca para ovos de poedeiras comerciais de diferentes linhagens e idades. Ciência Animal Brasileira; 2007; 8(1):25-29.

Card LE, Nesheim MC. Producion avicola. Zaragoza: Editoral Acribia; 1978.

Correia GMG, Takata FN, Medeiros JP, Barros ACS, Aguiar JFC, Evêncio Neto J. Efeito do tempo de armazenamento sobre a qualidade de ovos de aves tratadas com selênio orgânico. Revista Brasileira de Zootecnia. 2000; 29 (5):1440-1445.

Leandro NSM, Deus HAB, Stringhini JH. Aspectos de qualidade interna e externa de ovos comercializados em diferentes estabelecimentos na região de Goiânia. Ciência Animal Brasileira 2005; 6:71-78.

Moreng RE, Avens JS. Ciência e produção de aves. São Paulo: Roca; 1990 .

Moura AMA, Oliveira NTE, Thiebut JTL. Efeito da temperatura de estocagem e do tipo de embalagem sobre a qualidade interna dos ovos de codornas japonesas. Ciência Agrotécnica 2008; 32(2):578583.

Muller HG, Tobin G. Nutrición y ciencia de los alimentos. Zaragoza: Editoral Acribia; 1996.

Murakami AE, Ariki J. Produção de codornas japonesas. Jaboticabal: Funep-Unesp; 1998:79.

National Reserch Council. Recommended dietary allowances. 10th ed. Washington: National Academy; 1989.

Oliveira, GE. Influência da temperatura de armazenamento nas características físico-químicas e nos teores de aminas bioativas em ovos [dissertation]. Belo Horizonte(MG): Universidade Federal de Minas Gerais; 2006.

Panda B, Singh RP. Developments in processing quail meat and eggs. Poultry Science Journal 1990; 46:220-234.

Patricio IS. Manejo do ovo incubável da granja ao incubatório. In: Macari M, Gonzales E, editor. Manejo da incubação. Campinas: Facta; 2003 p. 163-179.

Piccinin, A, Onselen, VJV, Malhados, CHM. Técnicas de conservação da qualidade de ovos de codornas (Coturnix coturnix japonica) [cdrom]. Reunião Anual da Sociedade Brasileira de Zootecnia; 2004; Campo Grande, Mato Grosso do Sul. Brasil.

Rostagno HS, Albino LFT, Donzele JL, Gomes PC, Oliveira RF, Lopes
DC, Ferreira AS, Barreto SLT. Tabelas brasileiras para aves e suínos, composição dos alimentos e exigências nutricionais. 2 ed. Viçosa (MG): UFV-DZO; 2005.

Saeg - Sistema de Análises Estatísticas e Genéticas. Versão 9.0. Viçosa: Universidade Federal de Viçosa; 2005.

Scatolini AM. Mn, Zn e Se associados a moléculas orgânicas na alimentação de galinhas poedeiras no segundo ciclo de produção [dissertation]. Jaboticabal (SP): Universidade Estadual Paulista; 2007.

Sakanaka S, Kitahata K, Mitsuya T, Gutuerrez MA, Juneja, LR. Protein quality determination of delipidated egg-yolk. Journal of Food composition and Analysis 2000; 13:773-781.

Santos MSV, Espíndola GB, Lôbo RNB, Freitas ER, Guerra JLL, Santos ABE, Efeito da temperatura e estocagem em ovos. Ciência e Tecnologia de Alimentos 2009; 29(3):513-517.

Sauver B. El huevo para consumo: bases productivas.Madrid: Aedos Editorial; 1993.

Scott TA, Silversides FG. The effect of storage and strain of hen on egg quality. Poultry Science 2000; 79:1725-1729.

Souza PA, Souza HBA, Oba A, Gardini CHC. Influence of ascorbic acid on egg quality. Ciência e Tecnologia de Alimentos 2001; 21(3):273-275.

Stadelman WJ. The incredibly functional egg. Poultry Science 1999; 78:807-811.

Turatti JM. A importância dos ovos numa dieta saudável. Óleos e Grãos; 2001. p. 22-24. 